\title{
Evaluation of Serotonin as a Feedback Inhibitor of Lactation in the Bovine
}

\author{
L. L. Hernandez, ${ }^{\star}$ C. M. Stiening,† J. B. Wheelock, ${ }^{*}$ L. H. Baumgard, ${ }^{*}$ A. M. Parkhurst,‡ and R. J. Collier ${ }^{* 1}$ \\ *Department of Animal Sciences, University of Arizona, Tucson 85721 \\ †Cardiovascular Innovation Institute, University of Louisville, Louisville, KY 40202 \\ fDepartment of Statistics, University of Nebraska, Lincoln 68583
}

\section{ABSTRACT}

Serotonin (5-HT), a neurotransmitter synthesized from tryptophan, has been proposed as a feedback inhibitor of lactation. We determined that the gene coding for tryptophan hydroxylase 1, the rate-limiting enzyme for 5-HT synthesis, is expressed in bovine mammary epithelial cells in vitro and is upregulated by prolactin. In addition, 5-HT reduced the expression of $\alpha$-lactalbumin and casein genes in vitro. Furthermore, inhibiting 5-HT synthesis with $p$-chlorophenylalanine or blocking the 5-HT receptor with methysergide (METH) increased milk protein gene expression. We then evaluated effects of intramammary 5-HT or METH infusion on production and milk composition in 6 multiparous Holstein cows. Cows were assigned to a repeated measures design of contralateral intramammary infusions of METH ( $20 \mathrm{mg} /$ quarter per d) or saline for $3 \mathrm{~d}$ followed by a 7-d washout period before administering 5 -HT (50 $\mathrm{mg} / \mathrm{quarter} / \mathrm{d}$ ) or SAL for $3 \mathrm{~d}$. For each udder half, milk yield was recorded twice and composition was determined once per day. Blood samples were harvested each day for plasma to determine glucose and nonesterified fatty acid concentrations. Evaporative heat loss, respiration rate, left and right udder temperatures, and rectal temperatures were obtained after each milking to evaluate possible systemic effects of infusions. During METH and saline infusions milk yield increased $10.9 \%$. During 5-HT and saline infusion milk yield decreased $11.1 \%$. Milk yield and physiological responses suggested intramammary 5-HT and METH doses were high enough to cause systemic effects. Infusing saline, METH, and 5-HT increased milk SCC. Infusing 5-HT tended to reduce mean lactose concentration (4.3 vs. $4.6 \%)$ relative to saline. Milk protein content was decreased by METH and SAL $(2.0 \%)$ and was increased (5.8\%) by 5 -HT followed by a $33 \%$ decrease postinfusion. Infusion of METH increased evaporative heat loss $11 \%$,

Received October 9, 2007.

Accepted January 16, 2008.

${ }^{1}$ Corresponding author: rcollier@ag.arizona.edu which decreased $11 \%$ postinfusion. Infusions of 5-HT or METH did not affect plasma nonesterified fatty acid or glucose concentrations, respiration rate, or milk fat content. We conclude 5-HT infusion reduced milk synthesis, whereas blocking the 5-HT receptor with METH increased milk synthesis. Doses of 5-HT and METH used in this study likely resulted in systemic effects. These data support the concept that 5-HT is a feedback inhibitor of lactation in the bovine.

Key words: serotonin, milk production, dry-off, feedback inhibition of lactation

\section{INTRODUCTION}

Serotonin (5-HT) is a hormone and neurotransmitter synthesized from L-tryptophan and has been proposed to be a component of the autocrine-paracrine homeostatic feedback mechanism (feedback inhibitor of lactation), which opposes endocrine stimulation of mammary development and milk secretion (Wilde et al., 1995; Matsuda et al., 2004). The rate-limiting enzyme involved in synthesis of 5-HT is tryptophan hydroxylase (TPH). The TPH enzyme converts L-tryptophan to 5hydroxy-L-tryptophan. A second enzyme involved in 5HT synthesis is aromatic amino acid decarboxylase, which is responsible for the conversion of 5-hydroxy-Ltryptophan to 5-HT. Recently, 5-HT biosynthesis was induced in rodent mammosphere cultures by prolactin (PRL), and $\beta$-casein mRNA expression was suppressed by supplemental 5-HT (Matsuda et al., 2004). The same investigators demonstrated that systemic 5-HT administered to lactating rodents reduced litter weight gain, whereas administering a 5-HT receptor blocker increased litter weight gain, suggesting an up and down regulation of milk synthesis, respectively. Previous studies have reported presence of 5-HT in cow's milk (Zia et al., 1985) and that 5-HT is a potent vasoconstrictor in the sow mammary gland (Busk et al., 1999). Serotonin is also known to cause constriction of the smooth muscle in teat wall and sphincter (VandeputteVan Messon et al., 1985). However, to date, no one has demonstrated that 5-HT has any effects on gene 
expression in bovine mammary epithelial cells (BMEC) or has studied its effects on milk yield (MY) in lactating dairy cows. Our study objectives were to 1 ) evaluate the effects of PRL on TPH-1 gene expression in BMEC in a lactogenic model, 2) evaluate the effects of 5-HT and blockade of 5-HT synthesis, binding, or both on milk protein gene expression in BMEC in a lactogenic culture model, and 3) evaluate the effects of intramammary infusions of methysergide (METH; a nonselective 5-HT receptor blocker) and 5-HT on milk synthesis and composition. Additionally, the potential systemic effects of METH and 5-HT infusions were evaluated by measuring evaporative heat loss (EVHL), respiration rate $(\mathbf{R R})$, left udder temperature (LU), right udder temperature (RU), rectal temperature (RT), and circulating concentrations of energetic metabolites (glucose and NEFA). We hypothesized that 1) TPH-1 is expressed in bovine mammary cells and is upregulated by PRL, 2) 5-HT would decrease milk protein gene expression and blocking either its synthesis or binding to its receptor(s) would increase milk protein gene expression and, finally, 3) intramammary infusion of 5-HT would decrease MY, whereas blocking the 5-HT receptor(s) with METH would increase MY in lactating dairy cows.

\section{MATERIALS AND METHODS}

\section{Cell Culture and Sampling}

Tissue dissociation, BMEC isolation, and preparation of Type 1 collagen were performed according to Collier et al. (2006). Cell isolates were thawed, resuspended in DMEM/F-12, mixed with neutralized collagen, and cultured in 24-well plates as described (Collier et al., 2006). Stock collagen was neutralized on ice using 0.75 $N \mathrm{NaOH}$. A base layer $(300 \mu \mathrm{L} /$ well $)$ of neutralized collagen was added to a 24-well tissue culture plate (Falcon, BD Biosciences, San Jose, CA) and allowed to gel at room temperature for $5 \mathrm{~min}$. The resuspended cells were then added to the remaining neutralized collagen, and a 500- $\mathrm{L}$ collagen-cell suspension was seeded directly onto the base layer of each well. Collagen was then allowed to gel for 20 to $30 \mathrm{~min}$ at $37^{\circ} \mathrm{C}$; then appropriate medium was added to each well; and plates were then placed in an incubator at $37^{\circ} \mathrm{C}, 5 \%$ $\mathrm{CO}_{2}$ in air.

Cultures initially received a serum-free basal medium consisting of DMEM/F-12, 0.1\% BSA, antibioticantimycotic $(100 \mathrm{U} / \mathrm{mL}$ of penicillin, $100 \mu \mathrm{g} / \mathrm{mL}$ of streptomycin, and $0.25 \mu \mathrm{g}$ of amphotericin $\mathrm{B} ; 15240$, Invitrogen Corp., Carlsbad, CA). The growth factors (recombinant human IGF-I, $100 \mathrm{ng} / \mathrm{mL}$; A. F. Parlow, NIDDK, Torrance, CA) and recombinant-human epidermal growth factor (EGF; $25 \mathrm{ng} / \mathrm{mL} ; 13247-051$, In- vitrogen Corp.) were included to induce proliferation and ductal development. Media was exchanged every $48 \mathrm{~h}$ for $8 \mathrm{~d}$. Lactogenesis was induced after $8 \mathrm{~d}$ using the same basal medium without EGF, plus hydrocortisone (10 ng/mL; H-0396, Sigma, St. Louis, MO), recombinant bovine PRL (100 ng/mL; A. F. Parlow, NIDDK, Torrance, CA) and gel release (detachment of the polymerized collagen from the surface of the well). The effects of lactogenesis on TPH-1 gene expression were determined with and without PRL in the lactogenic medium. Samples receiving the lactogenic complex with PRL served as a positive control and without PRL served as a negative control to which treatments were compared: $4.2 \mu \mathrm{g} / \mathrm{mL}$ (20 $\mu M$ 5-HT; Sigma) with and without PRL, $9.38 \mu \mathrm{g} / \mathrm{mL}$ ( $20 \mu M$ METH; Sigma) with and without PRL, and $3.98 \mu \mathrm{g} / \mathrm{mL}$ [20 $\mu M p$-chlorophenyalanine (PCPA); Sigma] a 5-HT synthesis inhibitor with and without PRL. A total of 4 gels per replicate were used for RNA extraction, and 4 separate replicates of this design were carried out.

\section{Sample Preparation}

Total RNA was isolated from cell culture samples using TRIzol Reagent (Invitrogen). For precipitation, half of the recommended volume of isopropanol was used, with the other half being replaced with a salt solution ( $0.8 M$ sodium citrate, $1.2 \mathrm{M} \mathrm{NaCl})$. The RNA concentration, purity and integrity was confirmed on the 2100 BioAnalyzer (Agilent Technologies, Palo Alto, CA), as well as spectrophotometrically using a Nanodrop (ND-1000; Nanodrop Technologies, Wilmington, $\mathrm{DE})$.

\section{Real-Time Quantitative PCR}

One microgram of total RNA was DNase-treated at room temperature for $15 \mathrm{~min}$ in $10-\mu \mathrm{L}$ reaction containing $0.5 \mathrm{U}$ of DNase I (amplification grade, Invitrogen). The EDTA was added to a final concentration of $2.5 \mathrm{mM}$, and the DNase was inactivated at $65^{\circ} \mathrm{C}$ for 15 min. Resulting RNA was used for cDNA synthesis (20- $\mu \mathrm{L}$ reactions) using iScript cDNA synthesis Kit (BioRad, Hercules, CA). Analysis was conducted using the iCycler IQ Real-Time PCR Detection System (BioRad). Hypoxanthine phosphoribosyltransferase I (HPRT1) was used as the internal control gene following standard curve analysis across all treatment group samples [ribosomal protein (S18) and GAPDH were also evaluated]. Resulting gene expression data were calculated and analyzed based on the $2^{-\Delta \Delta \mathrm{CT}}$ method (Livak and Schmittgen, 2001). Primer sequences are shown in Table 1. 
Table 1. Sequences of primers used for quantitative real-time reverse transcription-PCR

\begin{tabular}{lll}
\hline Primer $^{1}$ & \multicolumn{1}{c}{ Forward primer $\left(5^{\prime}\right.$ to $\left.3^{\prime}\right)$} & \multicolumn{1}{c}{ Reverse primer (5' to $\left.3^{\prime}\right)$} \\
\hline$\beta$-Casein & GCTATGGCTCCTAAGCACAAAGA & GGAAACATGACAGTTGGAGGAAG \\
$\alpha$-Lactalbumin & CTCTGCTCCTGGTAGGCATC & ACAGACCCATTCAGGCAAAC \\
TPH1 & AGAGAATTTACCAAGACAATCAAGC & CTTAGCAAGGGCATCACTGAC \\
HPRT & GAGAAGTCCGAGTTGAGTTTGGAA & GGCTCGTAGTGCAAATGAAGAGT \\
\hline
\end{tabular}

\footnotetext{
${ }^{1} \beta$-Casein was run at an annealing temperature of $64^{\circ} \mathrm{C}, \alpha$-lactalbumin at $62^{\circ} \mathrm{C}$, and tryptophan hydroxylase-1 (TPH-1) at $61^{\circ} \mathrm{C}$. Hypoxanthine phosphoribosyltransferase (HPRT) was used as the housekeeping gene and was run at all annealing temperatures used for the primers of interest.
}

\section{Animals and Experimental Design}

The University of Arizona Institutional Animal Care and Use Committee approved all procedures involving animals.

Cows were housed at the University of Arizona Agricultural Research Complex in individual tie stalls and fed a TMR formulated to meet or exceed NRC recommendations (NRC, 2001). Cows were exposed to a 12$\mathrm{h}$ light/dark cycle and thermoneutral temperature of $20^{\circ} \mathrm{C}$. Diets were fed ad libitum at 0500 and $1700 \mathrm{~h}$, and animals had ad libitum access to water. The diet was primarily composed of alfalfa hay and corn (Table 2). Ration DM percentage and nutrient composition (Dairy One, Ithaca, NY) of the TMR were determined from a composite sample containing samples of feed from each week of the experiment. Cows were milked twice daily at 0500 and $1700 \mathrm{~h}$ during the 28 -d trials. Feed refusals were weighed and recorded before the $0500 \mathrm{~h}$ feeding. For statistical analyses, MY was recorded twice daily for each half-udder, and values were collapsed into a mean representative of the 6 milkings pretreatment infusion (period 1), 6 milkings of treatment infusion (period 2), and the 6 milkings posttreatment infusion (period 3). As a consequence, there were 3 periods associated with the METH and 5-HT infusions (3 periods/infusate). Milk yield was also calculated for the whole udder. Milk samples were obtained daily from each half-udder and analyzed for fat, true protein, lactose, and SCC (Arizona DHIA, Tempe, AZ). Milk fat, protein, and lactose were analyzed using AOAC-approved infrared analysis (AOAC, 2000); SCC was analyzed using AOAC-approved cell-staining techniques (AOAC, 2000). The International Dairy Federation and the Food and Drug Administration certified all equipment used in the analyses.

The study design used 6 multiparous, Holstein cull cows in late lactation (436 \pm 59 DIM; $703 \pm 68 \mathrm{~kg}$ of BW). Cows were removed from bST 1 mo prior to the start of the experiment. Cows selected for the study were healthy and had SCC $<500,000$ cells $/ \mathrm{mL}$. Within each animal, prior to METH treatment, contralateral udder halves were randomly assigned to an infusion of METH or SAL. During the 5-HT treatment period, contralateral udder halves that previously received SAL during the METH treatment received 5-HT, and contralateral udder halves that previously received METH received SAL. Immediately after each treatment infusion, all quarters received a short-acting antibiotic to prevent mastitis (Amoxi-Mast, amoxicillin trihydrate, Pfizer, Kalamazoo, MI). All milk from the study was discarded, and the animals were humanely euthanized and composted following the study.

\section{Intramammary Infusion}

Animals were allowed to acclimate for $7 \mathrm{~d}$ in the environmentally controlled rooms under thermoneutral conditions and remained under thermoneutral conditions for the remainder of the study. Both METH and 5 -HT were solubilized in sterile saline (at 2 and $17 \mathrm{mg} /$ $\mathrm{mL}$, respectively). Solutions were sterilized by syringe filtration $(0.22 \mu \mathrm{m})$ during dosing. Before administration, milk samples from all quarters of all cows were evaluated for mastitis using the California Mastitis Test. On d 8, $20 \mathrm{mg} /$ quarter per d of METH (\# M-137; Sigma) were infused (10 mg/quarter per milking) for $3 \mathrm{~d}$ in contralateral half-udders. Control udder-halves received a sterile SAL solution. After $3 \mathrm{~d}$ of METH infusions, animals were allowed a 7-d washout period. Following the washout period, udder halves previously receiving METH were assigned as the control udder

Table 2. Composition of the TMR (dry-weight basis) fed to late lactation cows $^{1,2}$

\begin{tabular}{lr}
\hline Ingredient & $\%$ TMR \\
\hline Alfalfa hay & 33.34 \\
Corn (steam-flaked) & 7.66 \\
Barley & 7.66 \\
Molasses (cane) & 0.75 \\
PF-45 high-producer premix & 4.59 \\
\hline
\end{tabular}

${ }^{1}$ Diet was $54 \% \mathrm{DM}$ and contained $20.5 \% \mathrm{CP}, 0.75 \mathrm{Mcal} \mathrm{NE} / \mathrm{kg}$ of $\mathrm{DM}, 26.2 \% \mathrm{ADF}$, and $31.4 \% \mathrm{NDF}$ based upon analysis of the TMR. Analysis was conducted by Dairy One Inc., Ithaca, NY.

${ }^{2}$ Contained $1.14 \times 10^{3} \mathrm{IU} / \mathrm{kg}$ of vitamin A, $1.09 \times 10^{2} \mathrm{IU} / \mathrm{kg}$ of vitamin $\mathrm{D}, 3.64 \mathrm{IU} / \mathrm{kg}$ of vitamin $\mathrm{E}, 0.55 \% \mathrm{Cl}, 1.84 \% \mathrm{~K}, 0.27 \% \mathrm{Mg}$, $0.36 \% \mathrm{Na}, 0.40 \% \mathrm{P}, 0.28 \% \mathrm{~S}, 1.39 \mathrm{ppm} \mathrm{Co}, 19.92 \mathrm{ppm} \mathrm{Cu}, 244.6 \mathrm{ppm}$ Fe, $0.82 \mathrm{ppm}$ I, $65.4 \mathrm{ppm} \mathrm{Mn}, 0.67 \mathrm{ppm}$ Mo, $0.33 \mathrm{ppm}$ Se, $62.4 \mathrm{ppm}$ $\mathrm{Zn}$. 
halves (SAL), and contralateral udder halves previously receiving SAL received $50 \mathrm{mg} /$ quarter per d of 5 -HT (Sigma; $25 \mathrm{mg} /$ quarter per milking) for $3 \mathrm{~d}$. After 5 -HT infusion, animals were monitored for an additional $7 \mathrm{~d}$.

\section{Measures of Potential Systemic Effects}

The following measurements were obtained twice daily ( 0500 and $1700 \mathrm{~h}$ ) on each cow: RR (counted by visual observation), EVHL (measured by a close chamber evapometer; Delfin Technologies, Kuopio, Finland), LU and RU surface temperatures (using an infrared thermister, Raytek, Santa Cruz, CA), and RT (YSI instruments, Yellow Springs, OH). Blood samples were obtained daily via the coccygeal vein, and plasma was harvested by centrifugation $(3,000 \times g)$ for $20 \mathrm{~min}$ at $4^{\circ} \mathrm{C}$. Concentration of plasma NEFA and glucose were measured in all samples (NEFA interassay $\mathrm{CV}=7.98 \%$, NEFA intraassay $\mathrm{CV}=8.30 \%$; glucose interassay $\mathrm{CV}=$ $6.74 \%$, intraassay $\mathrm{CV}=6.58 \%$; Wako Chemicals, USA, Richmond, VA).

\section{Statistical Analysis}

Cell Culture Experiment. A one-way ANOVA was conducted on quantitative real-time reverse-transcription-PCR data using gene expression relative to the negative control (lactogenic media, without PRL) in a respective sample, with the PROC MIXED procedure of SAS (SAS, 9.1, 2001; SAS Institute, Cary, NC). Graphical representation of data is represented by expression of treatments relative to the negative control $\left(2^{-\Delta \Delta \mathrm{CT}}\right)$. The $\Delta \Delta \mathrm{CT}$ was calculated as $\Delta \mathrm{CT}$ of a respective treatment minus $\Delta \mathrm{CT}$ of the negative control.

Animal Experiment. Two linear mixed models with repeated measures over twice daily milking time were used in the study. One model was used for intramammary infusion where milk and composition responses were measured on each udder within the animal.

$$
\mathrm{Y}_{\mathrm{ijk}}=\mu+\tau_{\mathrm{i}}+\gamma_{\mathrm{k}}+(\tau \gamma)_{\mathrm{ik}}+\mathrm{BX}_{\mathrm{ij}}+\mathrm{b}_{\mathrm{ij}}+\varepsilon_{\mathrm{ijk}},
$$

where $Y_{\mathrm{ijk}}$ is the response for the ith udder in jth cow at $\mathrm{kth}$ milking time adjusted for $\mathrm{BX}_{\mathrm{ij}}$, the baseline response just before infusion for the ith udder in the jth cow (B is the regression coefficient). The fixed effects are $\mu$, the mean response; $\tau_{\mathrm{i}}$, the effect of the ith udder treatment; $\gamma_{\mathrm{k}}$, the effect of the kth milking time; $(\tau \gamma)_{\mathrm{ik}}$, the interaction effect of the ith udder treatment and the kth milking time. The random effect $b_{i j}$ is the between-cow error associated with treatment given udder $\mathrm{i}$ for cow $\mathrm{j}$, whereas $\varepsilon_{\mathrm{ijk}}$ is the within-subjects error associated with ith udder treatment given to the jth cow on the kth day. The $b_{i j}$ are independently, identically distributed with a mean of 0 and a variance $\sigma_{\mathrm{b}}^{2}$. They are independent of $\varepsilon_{\mathrm{ijk}}$, which are assumed to be multivariate normal with mean zero and covariance matrix $\mathrm{R}$, where $\mathrm{R}$ is a block diagonal matrix, with one block, $\Sigma$, for each udder by cow within treatment.

The other model was for responses measured on the whole cow such as glucose, NEFA, LU, RU, SR, RT, and RR.

$$
\mathbf{Y}_{\mathrm{ijk}}=\mu+\tau_{\mathrm{i}}+\gamma_{\mathrm{k}}\left(\tau_{\mathrm{i}}\right)+\mathrm{b}_{\mathrm{ij}}+\varepsilon_{\mathrm{ijk}},
$$

where $Y_{i j k}$ is the response for the ith treatment period in jth cow at kth day, $\mu$ is the mean response, $\tau_{\mathrm{i}}$ is the effect of the ith treatment period, $\gamma_{\mathrm{k}}\left(\tau_{\mathrm{i}}\right)$ is the effect of the kth day nested in ith treatment period. The random effect of the jth cow in ith period is $b_{i j}$, whereas $\varepsilon_{i j k}$ is the period for the jth cow at the kth day. The $b_{i j}$ are independently, identically distributed with a mean of 0 and a variance $\sigma_{\mathrm{b}}^{2}$. They are independent of $\varepsilon_{\mathrm{ijk}}$, which are assumed to be multivariate normal with mean zero and covariance matrix $R$, where $R$ is a block diagonal matrix, with one block, $\Sigma$, for each cow within treatment period.

\section{RESULTS}

\section{Cell Culture Experiment}

The cell culture model used was a lactogenic rather than a galactopoietic model because there is presently no in vitro model of galactopoiesis. In this model, a serum-free growth medium supplemented with IGF-I and EGF was used to promote proliferation of BMEC for $8 \mathrm{~d}$, before the induction of differentiation. Bovine MEC embedded in collagen gels differentiate in response to a lactogenic complex consisting of IGF-I, PRL, and $\mathrm{HC}$, as well as releasing the gel from culture plate well (Steining, 2005; Steining et al., 2008). Lactogenic treatment induces dramatic morphological and ultrastructural differentiation representative of a BMEC undergoing stage I lactogenesis (Steining, 2005; Steining et al., 2008). Prolactin upregulated expression of the TPH-1 gene regardless of treatment $(P<0.004$, Figure 1 ), whereas PCPA, particularly in the absence of PRL, downregulated its expression $(P<0.0001$, Figure 1$)$. In 5-HT treated cultures with PRL, TPH-1 expression was upregulated $(P<0.05)$ relative to the negative control or 5-HT without PRL. Thus, PRL appears to upregulate expression of TPH-1 in BMEC and blocking TPH-1 enzyme activity, or the 5-HT receptor(s) was associated with downregulation of the TPH-1 gene.

The effects of 5-HT, the nonselective 5-HT receptor antagonist (METH), and an inhibitor of TPH-1 activity 


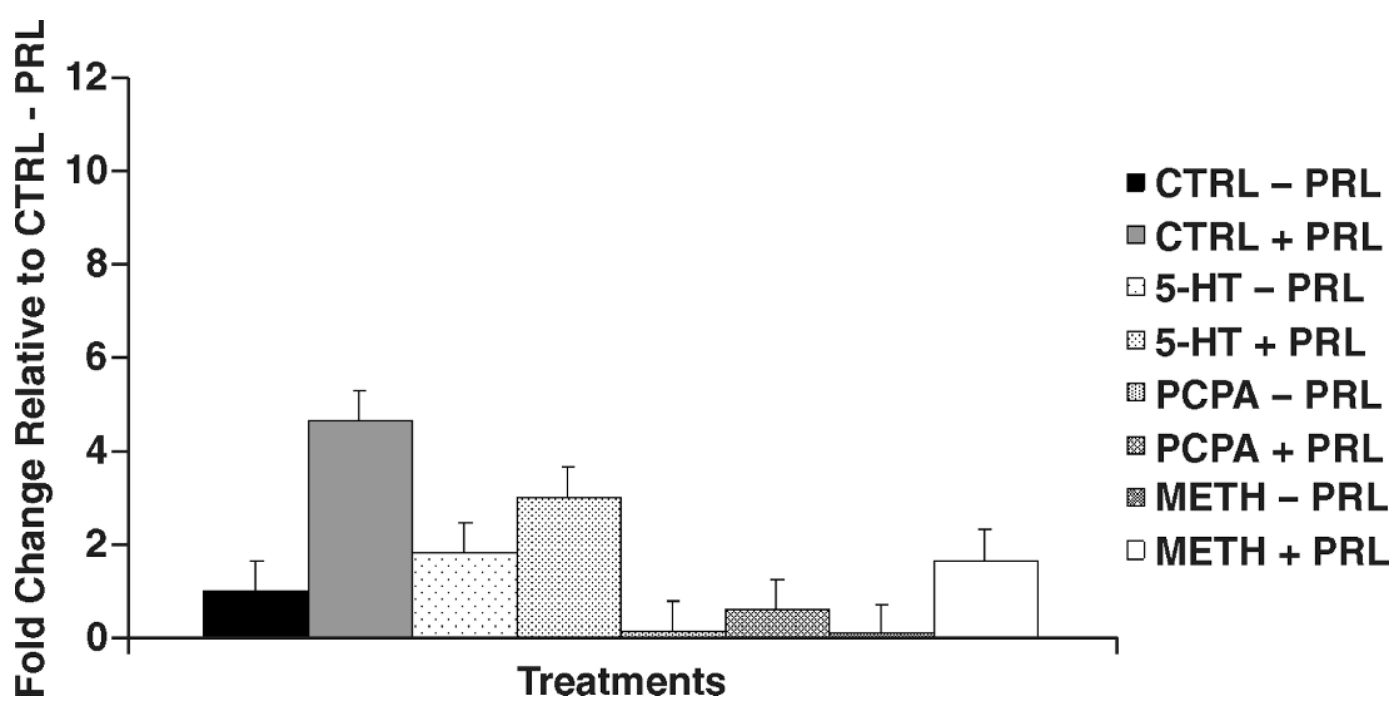

Figure 1. Effects of serotonergic agents with and without prolactin (PRL) on tryptophan hydroxylase 1(TPH-1) mRNA expression. Graph represents relative TPH-1 mRNA expression of treatments to control (CTRL) without PRL (negative control). Relative expression was calculated using $2^{-\Delta \Delta \mathrm{Ct}}$ method (Livak and Schmittgen, 2001). Statistical analysis was conducted on relative expression. Serotonin (5-HT) with PRL increased $(P<0.001)$ TPH-1 expression relative to all treatments except the control with PRL.

(PCPA) on milk protein gene expression were all tested using IGF-1 and hydrocortisone in the culture media with and without the presence of PRL. Exogenous 5-HT, with and without PRL, downregulated $\alpha$-lactalbumin mRNA expression relative to the control with PRL and PCPA with PRL $(P<0.05$; Figure 2$)$. The negative effects of 5-HT on $\alpha$-lactalbumin mRNA expression were rescued by the presence of METH with and without PRL, and upregulated by the presence of PCPA with PRL $(P<0.01$; Figure 2$)$. Additionally, $\beta$-casein mRNA expression was downregulated by exogenous $5-\mathrm{HT}$ and exhibited expression levels similar to the control without PRL (Figure 3). Downregulation of TPH-1 activity with PCPA, in combination with PRL, upregulated $\beta$ -

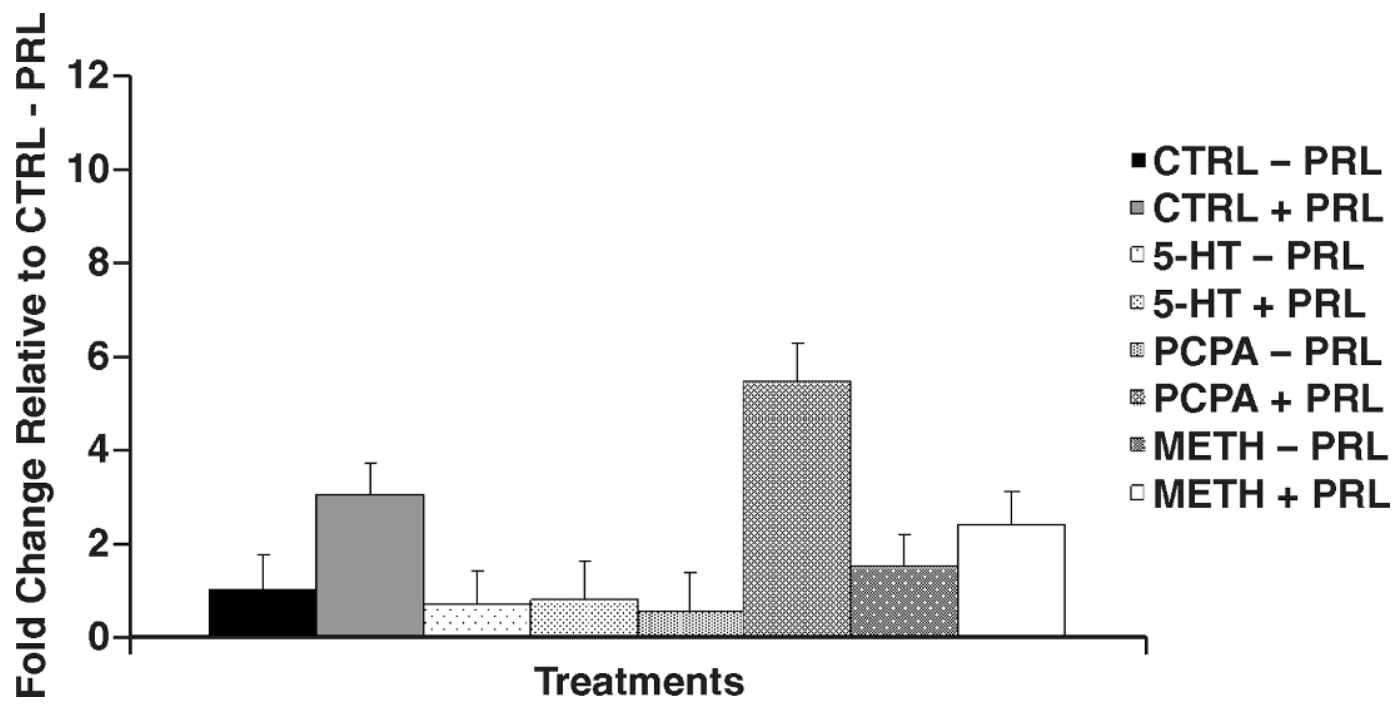

Figure 2. Effects of serotonergic agents with and without prolactin (PRL) on $\alpha$-lactalbumin mRNA expression. Graph represents relative $\alpha$-lactalbumin mRNA expression of treatments to control (CTRL) without PRL (negative control). Relative expression was calculated using $2^{-\Delta \Delta \mathrm{Ct}}$ method (Livak and Schmittgen, 2001). Statistical analysis was conducted on relative expression values. Serotonin (5-HT) with and without PRL decreased $(P<0.001) \alpha$-lactalbumin mRNA expression compared with CTRL with and without PRL. Addition of $p$ chlorophenyalanine (PCPA), a TPH-1 inhibitor, with PRL increased $\alpha$-lactalbumin gene expression relative to all treatments $(P<0.01)$. 




Figure 3. Effects of serotonergic agents with and without prolactin (PRL) on $\beta$-casein mRNA expression. Graph represents relative $\beta$ casein mRNA expression of treatments to control (CTRL) without PRL (negative control). Relative expression was calculated using $2^{-\Delta \Delta C t}$ method (Livak and Schmittgen, 2001). Statistical analysis was conducted on relative gene expression values. The bovine mammary epithelial cells cultured with serotonin (5-HT; $4.2 \mu \mathrm{g} / \mathrm{mL})$, with and without PRL (100 ng/mL), decreased $\beta$-casein mRNA expression $(P<0.001)$. Addition of $p$-chlorophenyalanine (PCPA; $3.98 \mu \mathrm{g} / \mathrm{mL}$; a TPH-1 inhibitor), with PRL, caused an increase in $\beta$-casein mRNA expression relative to all treatments, except the CTRL with PRL. Addition of methysergide (METH, $9.4 \mu \mathrm{g} / \mathrm{mL}$ ) increased $\beta$-casein gene expression relative to 5 -HT treatments $(P<0.05)$.

casein mRNA expression relative to all treatments $(P$ $<0.001$; Figure 3).

\section{Milk Yield and Composition}

The MY responses from the in vivo study are shown in Figures 4 and 5 and Table 3 . Whole udder MY increased $(10.9 \% ; P<0.01$; Figures 4 and 5) during METH infusion, and both udder halves responded similarly $(P>$ 0.05 ; Table 3 ). Milk yield from both udder halves decreased $11.1 \%$ during 5 -HT infusion $(P<0.05)$, and both udder halves responded similarly $(P<0.05$; Table 3$)$. These data indicate that the half-udder design was compromised by crossover or systemic effects of the compounds tested. Milk production did not differ between treated and control halves throughout the study $(P>$ 0.05).

Although there were no treatment effects on milk lactose percentage during METH infusion $(P>0.05$; Table 4$)$, there was a period $\times$ treatment interaction $(P$ $<0.05$; Table 4) as it decreased (3.2\%) during the METH infusion relative to the preinfusion period. Compared with controls, infusing 5 -HT tended to decrease milk lactose content $5.3 \%$ compared with SAL infusion $(P=$ 0.06 ; Table 5).

Milk protein percentage was decreased $(2.0 \% ; P<$ 0.01; Table 4) during METH and SAL infusion compared with postinfusion levels. Serotonin and SAL infusion increased milk protein content $7.3 \%$ compared with the postinfusion period. Infusing METH, 5-HT or SAL did not alter milk fat percentage $(P>0.05$; Tables 4 and 5 ). The changes in milk composition were detectable but quite small. However, large changes in component yield occurred because of the shift in milk volume. For instance, milk lactose yield declined $28 \%$ from pre- to post-5-HT infusion, whereas milk protein yield declined $20 \%$ during the same period.

\section{Systemic Effects}

Serotonin and SAL infusion increased EVHL during the infusion period by $33 \%$ compared with the postinfusion period $(P<0.0001$; Table 6$)$, tended to increase EVHL by $16.7 \%$ compared with the preinfusion period $(P=0.06$; Table 6$)$, and EVHL was $21.6 \%$ higher pre5 -HT infusion compared with post-5-HT infusion period $(P<0.01$; Table 6$)$. Infusing 5 -HT reduced EVHL compared with post-METH infusion $(P<0.01$; Table 6$)$; additionally, EVHL was $28.8 \%$ higher during METH infusion compared with post-5-HT infusion period $(P<$ 0.0001; Table 6). Serotonin infusion increased EVHL compared with post-METH infusion by $19.1 \%(P<0.01$; Table 6).

Infusing 5-HT and SAL tended to increase LU temperature by $1.2 \%$ compared with post-5-HT infusion period ( $P=0.07$; Table 6$)$. Left udder temperature was $1.6 \%$ higher post-METH infusion compared with post5 -HT infusion period $(P<0.01$; Table 6$)$, and LU temperature was $1.8 \%$ higher prior to METH infusion compared with post-5-HT infusion $(P<0.01$; Table 6$)$. Infus- 


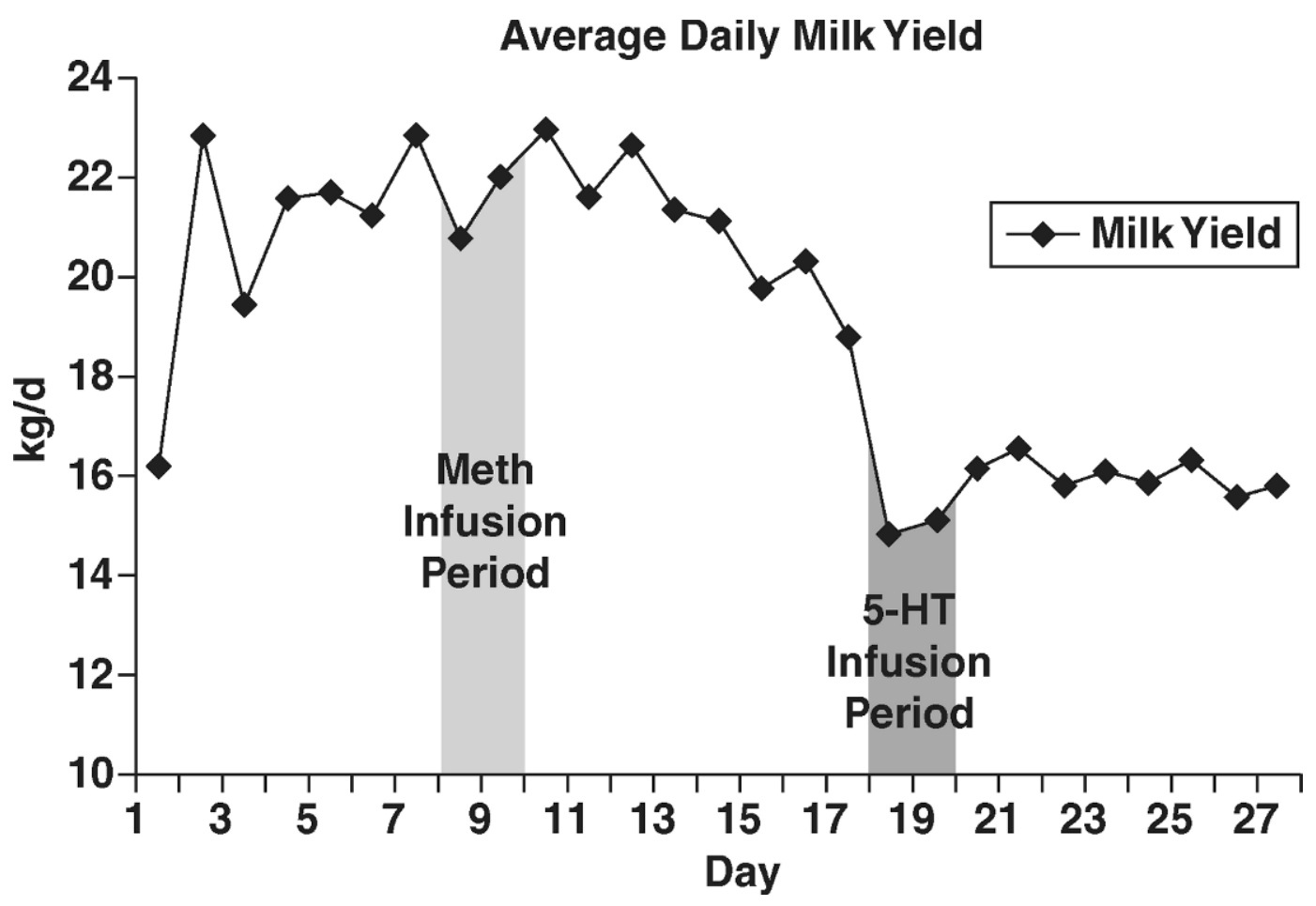

Figure 4. Average whole udder daily milk yield for whole udders of cows treated utilizing a half-udder model, with methysergide (METH) or saline (SAL) infusion on d 8, 9, and 10 and treated with serotonin (5-HT) or SAL on d 18, 19, and 20. Graph represents average daily whole-udder MY throughout the entire experiment.

ing METH tended increase RU temperature by $1.4 \%$ compared with 5 -HT infusion period $(P=0.07$; Table $6)$. Right udder temperature was $2.4 \%$ higher before METH compared with the post-5-HT infusion period ( $P$ $<0.0001$; Table 6). Serotonin infusion resulted in $1.4 \%$ decrease in RU temperature compared with postMETH infusion period ( $P=0.01$; Table 6$)$. Serotonin infusion resulted in a $3.0 \%$ decrease in rectal temperature compared with pre-5-HT infusion period and $4.1 \%$ compared with post-5-HT infusion period $(P=0.01$; Table 6). No effects of 5-HT or METH infusion were evident for NEFA or glucose concentration or RR $(P>$ 0.05 ; Tables 6 and 7).

\section{DISCUSSION}

Serotonin's role has not previously been evaluated in BMEC. There have been reports demonstrating that 5HT affects teat smooth muscle motility in the bovine (Vandeputte-Van Messon et al., 1985) and mammary vasculature contractility in the sow (Busk et al., 1999). We have demonstrated that TPH-1 (the rate limiting

Table 3. Average half-udder milk yields during the 6 milkings pre-, during, and post-serotonin (5-HT), methysergide (METH), and saline (CTL) infusions ${ }^{1}$

\begin{tabular}{lcccccc}
\hline Treatment & CTL & $($ SEM $)$ & TRT & $($ SEM $)$ & Mean $^{2}$ & $($ SEM) \\
\hline Pre-METH & 5.92 & $(0.81)$ & 4.92 & $(0.69)$ & $5.34^{\mathrm{a}}$ & $(0.64)$ \\
METH & 5.93 & $(0.81)$ & 5.17 & $(0.69)$ & $5.48^{\mathrm{a}}$ & $(0.58)$ \\
Post-METH & 6.01 & $(0.81)$ & 4.89 & $(0.69)$ & $5.30^{\mathrm{ab}}$ & $(0.48)$ \\
Pre-5-HT & 4.32 & $(0.69)$ & 5.29 & $(0.81)$ & $4.76^{\mathrm{ab}}$ & $(0.64)$ \\
5-HT & 3.50 & $(0.69)$ & 4.23 & $(0.81)$ & $4.23^{\mathrm{ab}}$ & $(0.58)$ \\
Post-5-HT & 3.69 & $(0.69)$ & 4.38 & $(0.81)$ & $4.04^{\mathrm{b}}$ & $(0.48)$ \\
\hline
\end{tabular}

\footnotetext{
${ }^{\mathrm{a}, \mathrm{b}}$ Values with different superscripts differ, $P<0.05$

${ }^{1}$ Average of 6 milkings for each udder half during each period. Udder halves did not differ between treatments.

${ }^{2}$ Mean milk yield for all udder halves during the respective period (kg/d).
} 


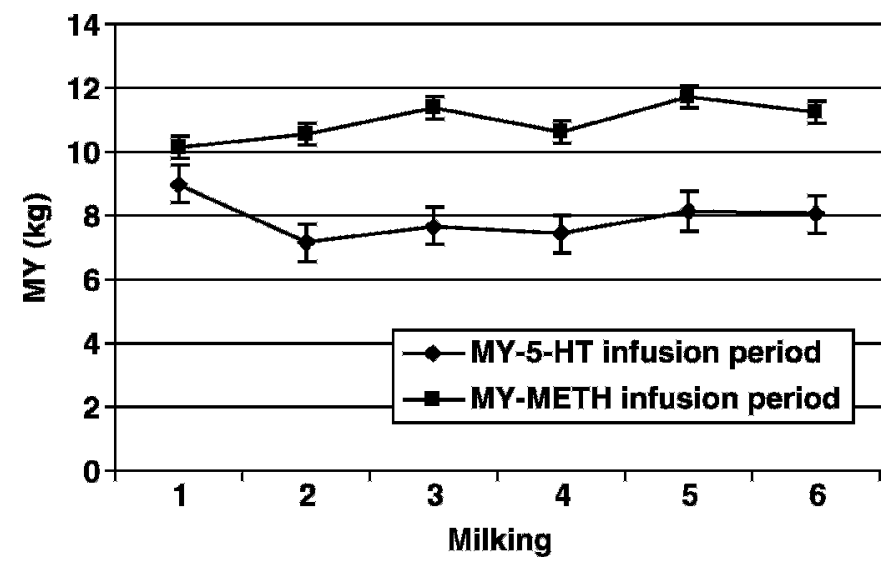

Figure 5. Average milk yield (MY) for whole udder for each milking during methysergide (METH) and saline (SAL) infusion (d 8, 9, and 10; 2 milkings per day) and during serotonin (5-HT) and SAL infusion (d 18, 19, and 20; 2 milkings per day). Graph represents average daily MY within the 2 treatment periods (METH or 5-HT infusion periods). Milk yield increased over time in both udder halves during the METH and SAL infusion period $(P<0.001)$. Milk yield decreased over time in both udder halves during $5-\mathrm{HT}$ and SAL infusion period $(P<0.01)$.

enzyme for 5-HT synthesis) is expressed in BMEC and is upregulated by PRL (Figure $1 ; P<0.001$ ) and was decreased by PCPA, which blocks TPH-1 action, relative to the control with PRL (Figure 1; $P<0.0001$ ). Furthermore, adding 5-HT to cultures containing lactogenic medium reduced mRNA expression of $\alpha$-lactalbumin and $\beta$-casein (Figures 2 and 3). Downregulation of milk protein mRNA expression by 5 -HT suggest that 5 -HT serves as a negative regulator of lactation. Additionally, rescue or enhancement of milk protein gene expression by inhibiting 5 -HT synthesis or downregulation of 5-HT receptor(s) further supports this hypothesis. Similar results were observed in primary mouse mammary epithelial cells (Matsuda et al., 2004). As stated earlier, in this study as well as Matsuda et al. (2004) and Stull et al. (2007), the in vitro models are all lactogenic as opposed to galactopoietic. In the case of $\alpha$-lactalbumin, a protein necessary for lactose synthesis, PCPA with PRL resulted in the highest level of mRNA expression. Inhibiting 5 -HT receptor(s) with METH, with and without PRL, rescued $\alpha$-lactalbumin gene expression relative to 5 -HT treated cells with and without PRL. The $\beta$-casein mRNA expression was also increased by PCPA with and without PRL and METH with and without PRL compared with 5 -HT with and without PRL. The largest increase in both $\alpha$-lactalbumin and $\beta$-casein mRNA expression was induced by the TPH-1 action inhibitor, PCPA in combination with PRL, indicating that both inhibition of 5-HT synthesis and stimulation by PRL is important in upregulating milk protein gene expression. Further increases in milk protein gene expression in BMEC might be possible if the specific 5-HT receptor(s) in the mammary gland were identified and blocked. There are numerous 5-HT receptor subclasses that function in different manners, such as inhibiting cAMP, stimulating cAMP, stimulating $\mathrm{IP}_{3}$ and diacylglycerol, and finally by stimulating ion channels (Glennon et al., 1995). Recently, the 5$\mathrm{HT}_{2 \mathrm{~A}}$ receptor subtype was identified in the MCF-7 human breast cancer cell line (Sonier et al., 2006). Furthermore, Stull et al. (2007) recently demonstrated that the $5-\mathrm{HT}_{7}$ receptor was present on the basolateral surface of human and mouse mammary epithelial cells and was involved in tight junction regulation. Antagonist and agonists for this receptor altered transepithelial electrical resistance, suggesting that one potential feedback action of 5-HT involves regulation of these junctions, which are critical to maintaining transepithelial gradients. Furthermore, they suggested that the route of 5-HT transfer from milk to the basolateral surface of the mammary epithelial cell was paracellular. Recently, we identified presence of the $5 \mathrm{HT}-1 \mathrm{~b}, 2 \mathrm{a}, 2 \mathrm{~b}, 4$, and 7 receptors in bovine mammary tissue (Hernandez et al., 2008). It is possible that some or all of these have direct or indirect effects on milk synthesis and

Table 4. Effects of intramammary infusions of methysergide (METH) on half-udder milk composition in Holstein cows ${ }^{1}$

\begin{tabular}{|c|c|c|c|c|c|c|c|c|c|c|}
\hline \multirow[b]{2}{*}{ Variable } & \multicolumn{2}{|c|}{ Pre-METH } & \multicolumn{2}{|c|}{ METH } & \multicolumn{2}{|c|}{ Post-METH } & \multirow[b]{2}{*}{ SEM } & \multicolumn{3}{|c|}{$P$-value ${ }^{2}$} \\
\hline & CTL & TRT & CTL & TRT & CTL & TRT & & Period & Udder & Interaction \\
\hline Fat, \% & 3.4 & 3.4 & 3.2 & 3.3 & 3.1 & 3.2 & 0.11 & 0.19 & 0.62 & 0.88 \\
\hline Lactose, \% & 4.6 & 4.7 & 4.5 & 4.5 & 4.5 & 4.6 & 0.07 & 0.01 & 0.67 & 0.04 \\
\hline Protein, \% & 3.4 & 3.3 & 3.3 & 3.3 & 3.4 & 3.4 & 0.03 & $<0.001$ & 0.78 & 0.64 \\
\hline $\mathrm{SCC}$ & 239.1 & 195.4 & 335.0 & 809.0 & 256.6 & 280.1 & 172.4 & 0.003 & 0.53 & 0.03 \\
\hline
\end{tabular}

${ }^{1}$ Data represent average concentrations of milk components during pre-METH infusion, METH intramammary infusion, and post-METH infusion. METH infusion of $20 \mathrm{mg} / q u a r t e r$ per $\mathrm{d}$ in a half-udder design using contralateral quarters, with the control half being infused with SAL. CTL = saline-infused udder half, TRT = METH-infused udder half.

${ }^{2}$ Significance of effects of the interaction between period and udder, period, and udder. 
Table 5. Effects of intramammary infusions of serotonin (5-HT) on half-udder milk composition in Holstein cows $^{1}$

\begin{tabular}{|c|c|c|c|c|c|c|c|c|c|c|}
\hline \multirow[b]{2}{*}{ Variable } & \multicolumn{2}{|c|}{ Pre-5-HT } & \multicolumn{2}{|c|}{$5-\mathrm{HT}$} & \multicolumn{2}{|c|}{ Post-5-HT } & \multirow[b]{2}{*}{ SEM } & \multicolumn{3}{|c|}{$P$-value ${ }^{2}$} \\
\hline & CTL & TRT & CTL & TRT & CTL & TRT & & Period & Udder & Interaction \\
\hline Fat, $\%$ & 3.3 & 3.1 & 3.4 & 3.5 & 3.8 & 3.9 & 0.28 & 0.04 & 0.90 & 0.84 \\
\hline Lactose, \% & 4.6 & 4.3 & 4.6 & 4.3 & 4.6 & 4.4 & 0.09 & 0.80 & 0.07 & 0.72 \\
\hline Protein, \% & 3.4 & 3.5 & 3.6 & 3.8 & 3.3 & 3.4 & 0.13 & 0.13 & 0.59 & 0.75 \\
\hline $\mathrm{SCC}$ & 197.3 & 248.8 & 504.2 & 548.1 & 326.0 & 309.3 & 93.32 & 0.005 & 0.83 & 0.89 \\
\hline
\end{tabular}

${ }^{1}$ Data represent average concentrations of milk components during pre-5-HT infusion, 5-HT intramammary infusion, and post-5-HT infusion. 5-HT infusion of $20 \mathrm{mg} / q u a r t e r / \mathrm{d}$ in a half-udder design using contralateral quarters, with the control half being infused with SAL. CTL = saline infused udder half, TRT = 5 -HT infused udder half.

${ }^{2}$ Significance of effects of the interaction between period and udder, period, and udder.

secretion. Thus, there are several potential sites of action for 5-HT on milk yield. It is known that 5-HT is a potent mammary vasoconstrictor (Vandeputte-Van Messon et al., 1985) and affects teat smooth muscle motility in the bovine (Vandeputte-Van Messon et al., 1985). Therefore, determining the specific pathway in which 5-HT exerts its inhibition is necessary to elucidate the mechanism of the action of 5-HT in the bovine mammary glad.

The effects of 5-HT and METH intramammary infusions on galactopoiesis have previously not been evaluated in the bovine. Milk yield was altered by intramammary infusions of both METH and 5-HT (Figures 4 and 5). However, data presented indicate the half-udder model design used in this study was compromised by crossover of the test compounds to the control udder half. This resulted in both halves demonstrating changes in milk yield that were consistent with the treatments administered. During the METH infusion, treated and nontreated udder halves demonstrated an $11 \%$ increase in yield (Figure 5). Likewise, infusing 5HT decreased MY (11.1\%) in treated and nontreated udder halves (Figure 5). The milk yield increase is impressive when considering the fact that these animals were more than $430 \mathrm{~d}$ in milk when they began the study. Previous rodent data suggests that inhibiting the 5-HT receptor subtypes increases mammary milk protein gene expression, and presumably therefore milk production (Matsuda et al., 2004). Increased MY in the SAL-treated udder halves during METH infusion and decreased MY in SAL udder halves during 5-HT treatment is likely due to a systemic response (i.e., carryover) of the infused compounds from the treated half to the control half through the systemic circulation. Evidence of a systemic response was indicated by marked changes in EVHL, occurring during METH and 5-HT infusion periods.

Although utilizing the half-udder milking model is useful, it is possible that 5-HT and METH were used in sufficiently high doses to reach the systemic system, causing a crossover of treatments. Additionally, because the identity of the 5-HT receptor subtype(s) in mammary tissue is unknown, we were unable to use a selective/specific 5-HT receptor subtype antagonist, which might have been effective on mammary tissue alone.

Treatments caused small but detectable changes in milk composition. Much greater changes were detected in yield of milk components due to changes in milk volume. Serotonin infusion tended to decrease milk lac-

Table 6. Effects of intramammary infusions of methysergide (METH) and serotonin (5-HT) on systemic responses in Holstein cows ${ }^{1}$

\begin{tabular}{lccccc}
\hline Treatment period & LU $\left({ }^{\circ} \mathrm{C}\right)$ & $\mathrm{RU}\left({ }^{\circ} \mathrm{C}\right)$ & $\mathrm{RT}\left({ }^{\circ} \mathrm{C}\right)$ & EVHL $\left(\mathrm{g} / \mathrm{m}^{2}\right.$ per h) & RR $($ breath/min $)$ \\
\hline Pre 1 & $34.07(0.13)^{\mathrm{a}}$ & $34.02(0.12)^{\mathrm{a}}$ & $38.75(0.19)^{\mathrm{a}}$ & $50.35(2.02)^{\mathrm{a}}$ & $39.44(0.93)^{\mathrm{a}}$ \\
METH & $33.93(0.19)^{\mathrm{ab}}$ & $33.81(0.19)^{\mathrm{a}}$ & $38.71(0.31)^{\mathrm{a}}$ & $56.16(3.06)^{\mathrm{a}}$ & $38.50(1.41)^{\mathrm{a}}$ \\
Post 1 & $34.00(0.17)^{\mathrm{ab}}$ & $33.82(0.16)^{\mathrm{ab}}$ & $38.52(0.12)^{\mathrm{a}}$ & $49.96(2.69)^{\mathrm{a}}$ & $39.27(1.24)^{\mathrm{a}}$ \\
Pre 2 & $33.83(0.20)^{\mathrm{ab}}$ & $33.56(0.19)^{\mathrm{a}}$ & $38.47(0.17)^{\mathrm{a}}$ & $50.99(3.43)^{\mathrm{a}}$ & $38.67(1.43)^{\mathrm{a}}$ \\
5-HT & $33.89(0.19)^{\mathrm{ab}}$ & $33.35(0.18)^{\mathrm{bc}}$ & $37.31(0.38)^{\mathrm{b}}$ & $59.51(3.02)^{\mathrm{a}}$ & $39.37(1.39)^{\mathrm{a}}$ \\
Post 2 & $33.47(0.13)^{\mathrm{b}}$ & $31.20(0.12)^{\mathrm{c}}$ & $38.85(0.19)^{\mathrm{a}}$ & $39.99(2.02)^{\mathrm{b}}$ & $38.49(0.93)^{\mathrm{a}}$ \\
\hline
\end{tabular}

${ }^{\mathrm{a}-\mathrm{c}}$ Values within a column with different superscripts differ, $P<0.05$.

${ }^{1}$ Data represent least square means of $\mathrm{LU}=$ left udder, $\mathrm{RU}=$ right $\mathrm{udder}, \mathrm{RT}=$ rectal temperature, $\mathrm{SR}=$ sweating rate, and $R R=$ respiration rate. Standard errors for individual means are listed in parentheses.

${ }^{2}$ Pre $1=$ pre-METH infusion period, METH = METH infusion period, Post 1 = post-METH infusion period, Pre $2=$ pre-5-HT infusion period, 5-HT $=5$-HT infusion period, Post $2=$ post-5-HT infusion period. 
Table 7. Effects of intramammary infusions of methysergide (METH) and serotonin (5-HT) on plasma metabolites in Holstein cows ${ }^{1}$

\begin{tabular}{|c|c|c|}
\hline Treatment period ${ }^{2,3}$ & NEFA, $\mu \mathrm{Eq} / \mathrm{L}$ & Glucose, mg/dL \\
\hline Pre 1 & $173.36(24.48)$ & $92.38(2.47)$ \\
\hline METH & $147.11(36.12)$ & $92.70(3.64)$ \\
\hline Post 1 & $94.51(30.40)$ & $93.06(3.13)$ \\
\hline Pre 2 & $142.08(35.10)$ & $94.39(3.64)$ \\
\hline $5-\mathrm{HT}$ & $167.29(34.17)$ & $91.51(3.54)$ \\
\hline Post 2 & $178.83(24.16)$ & $91.64(2.41)$ \\
\hline
\end{tabular}

${ }^{1}$ Data represent least square means of NEFA and glucose concentrations of plasma. Standard errors for individual means are listed in parentheses.

${ }^{2}$ Pre 1 = pre-METH infusion period, METH = METH infusion period, Post $1=$ post-METH infusion period, Pre $2=$ pre-5-HT infusion period, $5-\mathrm{HT}=5-\mathrm{HT}$ infusion period, Post $2=$ post-5-HT infusion period.

${ }^{3}$ Values did not differ $(P>0.05)$.

tose percentage. Previous research indicates that 5-HT suppresses $\alpha$-lactalbumin expression in mouse and bovine mammary epithelial cell culture (Matsuda et al., 2004; Stiening, 2005). No treatment effect (vs. SAL) on milk lactose occurred during METH infusion. Milk lactose concentration decreased slightly during METH infusion compared with the pre-METH infusion period. Small increases in milk protein content were detected during METH infusion relative to the pre- and post-5HT infusion periods. This is further evidence that METH and 5-HT likely entered the systemic circulation, resulting in milk protein being altered in both udder halves (regardless of treatment) and the response paralleled that of MY (Figure 4). In previous studies, antagonizing the mammary epithelial cells 5-HT receptors with METH has increased milk protein mRNA expression indicating that overall milk protein synthesis should increase (Matsuda et al., 2004). Additionally, treating mammary epithelial cells with 5-HT reduced milk protein mRNA expression, indicating that overall milk protein synthesis would be decreased. Although our results are consistent with previous rodent research, changes in milk composition were minor.

Milk SCC was increased during both METH and 5$\mathrm{HT}$, regardless of treatment (vs. SAL). Intramammary infusions can activate the mammary immune system. This occurs due to the potential of the syringe cannula to dilate the lumen of the streak canal, causing removal of keratin or causing preexisting microorganisms to move from the streak canal to the teat cistern (Akers, 2002). It is likely not due to endotoxin in the infusate because each infusion was filtered $(0.22 \mu \mathrm{m})$ during the infusion process. Although SCC increased above 400,000 cells/mL during infusion periods, no clinical mastitis was detected in any of the cows as determined by the California Mastitis Test.
We detected reduced EVHL in cows, post-5-HT infusion compared with all other periods. This may have been associated with reduced cutaneous blood flow. There were significant changes in LU and RU temperatures and RT, further supporting the idea that both infusions of METH and 5-HT resulted in a systemic response. Nonthermal factors can attenuate or enhance cold-induced vasoconstriction, heat-induced vasodilation, or both, similar to thermal environmental factors (Mekjavic and Eiken, 2006). Temperature of the RU during 5-HT infusion was significantly lower than pre5-HT infusion, METH infusion period, and pre-METH infusion. Temperature of the LU was significantly lower post-5-HT infusion compared with pre-METH infusion period. Rectal temperatures of cows were decreased during the 5-HT infusion period compared with all other periods. Administration of 5-carboxytryptamine, an agent that increases 5-HT levels, both systemically and in the cerebral ventricles in guinea pigs, resulted in a dose-dependent reduction in core body temperature (Hagan et al., 2000). Receptors 5- $\mathrm{HT}_{1 \mathrm{a} / 7}$ have been shown to be involved in regulation of core body temperature by causing hypothermia when activated (Faure et al., 2006). The 5- $\mathrm{HT}_{2 \mathrm{a}}$ receptor has been demonstrated to be involved in inducing hyperthermia when activated (Pawlyk et al., 2006). When the $5-\mathrm{HT}_{2 \mathrm{a}}$ receptor is antagonized with a systemic dose of mirtazapine, core body temperature is decreased. Therefore, it is likely that udder skin temperature changed due to 5-HT reaching the systemic circulation and acting on subsequent receptor subtypes involved in thermoregulatory processes.

\section{CONCLUSIONS}

These studies were designed to determine if the ratelimiting gene for 5-HT synthesis was expressed in bovine mammary tissue and upregulated by PRL. In addition we wanted to determine if 5-HT and a nonselective antagonist of 5-HT receptors, METH, altered milk protein gene expression in BMEC and milk production in lactating Holstein cows. Downregulation of milk protein gene expression by 5-HT in cultures of BMEC and upregulation of these genes using inhibitors of the serotonergic system support the concept that 5 -HT is a feedback inhibitor of lactation in the bovine. The MY and systemic response data indicate that the dose used resulted in crossover of treatments compromising the half-udder design. Milk yields did not differ between treatment and control halves for either treatment. However, the whole udder response in MY and composition support the concept of 5-HT as a feedback inhibitor of lactation in the bovine. Additionally, results of this study support the need to characterize the bovine sero- 
tonergic system (i.e., receptor subtypes and pathways being stimulated) to fully understand how MY is locally regulated in the mammary gland.

\section{ACKNOWLEDGMENTS}

Authors would like to thank the Monsanto Company for funding this research. Additionally, they would like to thank Nelson Horseman (Dept. Molecular Cellular Physiol., Univ. Cincinnati, OH) for his input on this research.

\section{REFERENCES}

Akers, R. M. 2002. Lactation and the Mammary Gland. Iowa State Press, Ames, IA.

AOAC. 2000. Official Methods of Analysis. 17th ed. Association of Official Analytical Chemists International, Arlington, VA.

Busk, H., M. T. Sorensen, E. O. Mikkelsen, M. O. Nielsen, and K. Jakobsen. 1999. Responses to potential vasoactive substances of isolated mammary blood vessels from lactating sows. Comp. Biochem. Physiol. C. Pharmacol. Toxicol. Endocrinol. 124:57-64.

Collier, R. J., C. M. Stiening, B. C. Pollard, M. J. VanBaale, L. H. Baumgard, P. C. Gentry, and P. M. Coussens. 2006. Use of gene expression microarrays for evaluating environmental stress tolerance at the cellular level in cattle. J. Anim. Sci. 84:E1-E13.

Faure, C., O. Mnie-Filali, H. Scarna, G. Debonnel, and N. Haddjeri. 2006. Effects of the 5-HT7 receptor antagonist SB-269970 on rat hormonal and temperature responses to the 5 -HT1A/7 agonist 8OH-DPAT. Neurosci. Lett. 404:122-126.

Glennon, R. A., M. Dukat, and R. B. Westkaemper. 1995. Serotonin receptor subtypes and ligands. Pages 1-25 in Psychopharmacology: The Fourth Generation of Progress. F. E. Bloom and D. J. Kupfer, ed. Raven Press, New York, NY.

Hagan, J. J., G. W. Price, P. Jeffrey, N. J. Deeks, T. Stean, D. Piper, M. I. Smith, N. Upton, A. D. Medhurst, D. N. Middlemiss, G. J. Riley, P. J. Lovell, S. M. Bromidge, and D. R. Thomas. 2000. Characterization of SB-269970-A, a selective 5-HT7 receptor antagonist. Br. J. Pharmacol. 130:539-548.

Hernandez, L. L., S. W. Limesand, L. H. Baumgard, N. D. Horseman, and R. J. Collier. 2008. Characterization of the bovine mammary serotonergic system. FASEB Proc. Abstract \# 1812.
Livak, K. J., and T. D. Schmittgen. 2001. Analysis of relative gene expression data using real-time quantitative PCR and the 2-delta, delta Ct method. Methods 25:402-408.

Matsuda, M., T. Imaoka, A. J. Vomachka, G. A. Gudelsky, Z. Hou, M. Mistry, J. P. Bailey, K. M. Nieport, D. J. Walther, M. Bader, and N. D. Horseman. 2004. Serotonin regulates mammary gland development via an autocrine-paracrine loop. Dev. Cell 6:193203.

Mekjavic, I. B., and O. Eiken. 2006. Contribution of thermal and nonthermal factors to the regulation of body temperature in humans. J. Appl. Physiol. 100:2065-2072.

National Research Council. 2001. Nutrient Requirements of Dairy Cattle. 7th rev. ed. Natl. Acad. Press, Washington, DC.

Pawlyk, A. C., S. Cosmi, P. D. Alfinito, N. Maswood, and D. C. Deecher. 2006. Effects of the 5-HT2a antogonist mirtazapine in rat models of thermoregulation. Brain Res. 1123:135-144.

SAS Institute. 2001. SAS/STAT User's Guide. Version 8.0. SAS Inst., Inc., Cary, NC.

Sonier, B., M. Arseneault, C. Lavigne, R. J. Ouellette, and C. Vaillancourt. 2006. The 5-HT2a serotoninergic receptor is expressed in the MCF-7 human breast cancer cell line and reveals a mitogenic effect of serotonin. Biochem. Biophys. Res. Commun. 343:10531059.

Stiening, C. M. 2005. Genomic regulation of bovine mammary epithelial cell growth and differentiation. PhD Diss. University of Arizona, Tucson.

Stiening, C. M., J. B. Hoying, M. B. Abdallah, A. M. Hoying, R. Pandey, K. Greer, and R. J. Collier. 2008. The effects of endocrine and mechanical stimulation on stage I lactogenesis in bovine mammary epithelial cells. J. Dairy Sci. 91:1053-1066.

Stull, M. A., V. Pai, A. J. Vomachka, A. M. Marshall, G. A. Jacob, and N. D. Horseman. 2007. Mammary gland homeostasis employs serotonergic regulation of epithelial tight junctions. Proc. Natl. Acad. Sci. USA 104:16708-16713.

Vandeputte-Van Messon, G., C. Burvenich, and G. Peeters. 1985. Effect of serotonin on the motility of smooth muscles in teats of lactating cows. J. Dairy Res. 52:347-353.

Wilde, C. J., C. V. P. Addey, L. M. Boddy, and M. Peaker. 1995. Autocrine regulation of milk secretion by a protein in milk. Biochem. J. 305:51-58.

Zia, S., S. N. Giri, J. Cullor, P. Emau, B. I. Osburn, and R. B. Bushnell. 1985. Role of eicosanoids, histamine and serotonin in the pathogenesis of Klebsiella pneumoniae-induced bovine mastitis. Am. J. Vet. Res. 48:1617-1625 